\title{
精神科入院患者における向精神薬使用と転倒・転落リスク
}

\author{
佐野知子, ${ }^{*, a}$ 原田雅史, ${ }^{a}$ 菅原隆光, ${ }^{b}$ 伊坂直紀, ${ }^{c}$ \\ 増岡昭生, ${ }^{d}$ 三上昭廣, ${ }^{e}$ 島森美光, ${ }^{f}$ 黒澤菜穂子 $f$
}

\section{Use of Psychotropics and the Risk of Falls in Hospitalized Psychiatric Patients}

\author{
Tomoko Sano, ${ }^{*, a}$ Masashi Harada, ${ }^{a}$ Takamitsu Sugawara, ${ }^{b}$ Naoki Isaka, ${ }^{c}$ \\ Akio Masuoka, ${ }^{d}$ Akihiro Mikami, ${ }^{e}$ Yoshimitsu Shimamori, ${ }^{f}$ and Nahoko Kurosawa ${ }^{f}$ \\ ${ }^{a}$ Department of Phamacy, Hakodate Watanabe Hospital; ${ }^{b}$ Department of Dermatology, Hakodate Watanabe \\ Hospital; 'Department of Surgery, Hakodate Watanabe Hospital; ${ }^{d}$ Department of Orthopedics, Hakodate \\ Watanabe Hospital; ${ }^{e}$ Department of Psychiatry, Hakodate Watanabe Hospital; 1-31-1 Yunokawa-cho, \\ Hakodate, Hokkaido 042-8678, Japan: and ${ }^{f}$ Hokkaido Pharmaceutical University School of \\ Pharmacy; 7-1 Katsuraoka-cho, Otaru, Hokkaido 047-0264, Japan.
}

(Received January 7, 2013; Accepted April 27, 2013)

\begin{abstract}
As hospitalized patients in psychiatry departments are often prescribed multiple psychotropics depending on their psychiatric symptoms, psychotropics are considered as important factors potentially associated with a high risk of falls. In this study, we attempted to investigate, from the aspect of drug prescription, to what degree the number and doses of psychotropics must be adjusted in order to reduce risk of falls in hospitalized psychiatric patients. The subjects were 526 patients, consisting of a fall group of 313 patients, who had experienced 1 to 5 falls (510 events) and a control group of 213 patients who had never experienced falls. Multiple logistic regression analysis was performed to determine the correlations between the occurrence of falls and the number and doses of psychotropics. The results showed that the risk of falls increased with increasing number of antipsychotics and anxiolytics/hypnotics prescribed, with the risk increasing, by 3.75 -fold with the increase in the dose of chlorpromazine $(\mathrm{CP})$-equivalents to more than $600 \mathrm{mg}$, by 2.08 -fold when the dose of diazepam (DAP)-equivalents to more than $15 \mathrm{mg}$, and by 7.80 -fold with increase in CP-equivalents to more than $600 \mathrm{mg}$ concomitantly with an increase in DAP-equivalents to more than $15 \mathrm{mg}$. In addition, a tendency towards increase in the frequency of falls was observed when more than 5 psychotropics were prescribed concomitantly. The above results suggested that the risk of falls may be reduced by appropriately adjusting the number of drugs and the doses of psychotropics used in the treatment of psychiatric disorders.
\end{abstract}

Key words_ fall; psychotropics; risk management; chlorpromazine (CP)-equivalent; diazepam (DAP)-equivalent

\section{緒 言}

医療機関において発生する医療事故の中で，転 倒・転落事故の占める割合はとても大きい。転倒・ 転落事故が発生するに至るには，複数の要因がこれ に関与することが知られている.1,2) そして，転倒・ 転落による骨折あるいはそれによる誛たきりや再転 倒への心理的不安は患者の activities of daily living (ADL) や quality of life (QOL) に大きな影響を及

The authors declare no conflict of interest.

$a$ 社会医療法人函館渡辺病院薬剤部, $b$ 社会医療法人函 館渡辺病院皮膚科, ${ }^{c}$ 社会医療法人函館渡辺病院外科, $d$ 社会医療法人函館渡辺病院整形外科, $e$ 社会医療法人 函館渡辺病院精神科, $f$ 北海道薬科大学

*e-mail: tomombox@cameo.plala.or.jp
ぼし，患者の社会復帰を妨げる原因にもなつている. 函館渡辺病院（精神科 512 床, 一般病床 120 床, 以下当院）においても転倒・転落事故を防止するた めに段差や障害物, 履物といつた外的要因に関し て，環境調整などの対策を講じてきた。 それにもか かわらず，2009年 4 月からの 2 年間に発生した医 療事故の $53 \%(714 / 1345 ）$ が転倒・転落事故であ り，その後も転倒・転落事故は減少には至っていな い.

精神科に入院中の患者には，その精神症状により 複数の向精神薬が処方される場合が多い。そのた め, 精神科における入院患者の転倒・転落の原因 は, 身体疾患, 加齢変化, 使用薬剂といつた転倒 ・ 転落の内的要因の中でも, 特に向精神薬の関与が大 
きいのではないかと推察される。これまで, 向精神 薬の中でベンゾジアゼピン系抗不安薬・睡眠薬の転 倒・転落リスクに関してはいくつか報告されてい る. ${ }^{3-6)}$ しかしながら，抗精神病薬に関する転倒・ 転落リスクの報告は少なく, また, ベンゾジアゼピ ン系抗不安薬・睡眠薬と抗精神病薬の併用による転 倒・転落リスクの報告も少ない，

転倒・転落リスクを減らすためには，1）転倒・ 転落リスクの低い安全な薬剤を選択する（リスクの 高い薬剤を処方しない)，2）転倒・転落リスクの高 い薬剤の処方剂数を減らす（又は中止する），3）転 倒・転落リスクの高い薬剤の投与量を減らす（又は 中止する）などの手段が考えられる．しかし，精神 科での入院患者においては，その疾患の治療上，向 精神薬の処方を中止することは難しく，処方を見直 し，転倒・転落リスクを減少させるためには更なる 情報が必要となる。そこで，本研究では転倒・転落 リスクを処方薬剤から，向精神薬の剂数及び投与量 をどの程度調整すれば転倒・転落リスクを減らすこ とができるかを調査することを目的に，向精神薬の 服用と転倒・転落事故との関連性について検討した ので報告する.

\section{方法}

1. 調査期間と対象 当院において 2009 年 4 月 1 日より 2011 年 3 月 31 日までの 2 年間に発生し た転倒・転落事故件数は 714 件であったそそのうち 転倒・転落回数が 1-5 回の患者 313 名（510 件）を case 群とし，転倒・転落歴のない患者 213 名（213 件）を control 群として，合計 526 名（723 件）の 入院患者を対象とした.

2. 調査項目 処方薬調查は電子カルテの情報 を基に, case 群は転倒・転落事故発生日の服用薬 について, control 群は入院期間において前後 1 週 間に処方変更のない 1 日の服用薬について向精神薬 の剂数及び投与量 [気分安定薬の処方量, クロルプ ロマジン (chlorpromazine; CP) 換算量, ジアゼパ ム（diazepam; DAP）換算量を調査した。CP 及 びDAP の等価換算には，稲垣・稲田による換算 表7)を用いた。

\section{3. 統計学的解析}

3-1. control 群と各 case 群の比較 男女の割 合については $\chi^{2}$ 検定，年齢については一元配置分
散分析を行うことにより, control 群と各 case 群の 比較を行った。

\section{3-2. 転倒・転落リスクと向精神薬の剂数及び投} 与量との関係転倒・転落リスクと全向精神薬剂 数との関係について検討するために，目的変数を転 倒・転落の有無, 説明変数を全向精神薬剂数として ロジスティック回帰分析を行った。また，転倒・転 落リスクと各向精神薬の剂数との関係について検討 するために, 気分安定薬, 抗精神病薬, 抗パーキン ソン薬，抗不安薬・睡眠薬，抗うつ薬それぞれの剤 数を説明変数として多重ロジスティック回帰分析を 行った.

転倒・転落リスクと投与量との関係については, 目的変数を転倒・転落の有無, 説明変数を転倒・転 落リスクを有意に増加させた抗精神病薬及び抗不安 薬・睡眠薬の投与量とし，ロジスティック回帰分析 を行った。実際には，クロルプロマジン $(\mathrm{CP})$ 換 算量 (CP 換算量 $600 \mathrm{mg}$ を基準とし，CP $600 \mathrm{mg}$ 以上と CP $600 \mathrm{mg}$ 未満の 2 群について), ジアゼパ ム（DAP）換算量（ジアゼパムの添付文書で示さ れている用量 $15 \mathrm{mg}$ を基準として DAP 換算量で比 較し DAP $15 \mathrm{mg}$ 以上と DAP $15 \mathrm{mg}$ 未満の 2 群に ついて）を説明変数に用いた。

なお，上記 3-1. 及び 3-2. のすべて統計学的解析 において，有意水準を危険率 5\%未満とした。

4. 倫理的配慮 本研究は当院倫理委員会の承 認を得て実施した.

\section{結果}

1. 患者背景 転倒・転落回数によって分けた 各群（転倒・転落なし，転倒・転落 1 回，2 回，3 回，4 回，5 回）における患者背景を Table 1 に示 す.

各群間において, 男女の割合に関する有意差は認 められなかった（ $\chi^{2}$ 検定， $\left.p=0.942\right) 。$ また，年齢 に関する有意差も認められなかった（一元配置分散 分析, $p=0.840$ ).

\section{2. 処方薬剂の影響}

2-1. 処方向精神薬の内訳 今回，検討した処 方向精神薬のリストを Table 2 に示す．全部で， 67 種類あり，その内訳は，抗精神病薬 (16), 気分安 定薬 (3), 抗パーキンソン薬 (6), 睡眠薬・抗不安 薬 (25), 抗うつ薬 (17) であった. 
Table 1. Comparison of Characteristics of Fallers and Non-fallers

\begin{tabular}{|c|c|c|c|c|c|c|c|c|c|c|}
\hline \multicolumn{3}{|c|}{ Patient $(n)$} & $\begin{array}{l}\text { Total } \\
(526)\end{array}$ & $\begin{array}{l}\text { No fall } \\
(213)\end{array}$ & $\begin{array}{l}\text { One fall } \\
(201)\end{array}$ & $\begin{array}{l}\text { Two falls } \\
\text { (62) }\end{array}$ & $\begin{array}{l}\text { Three falls } \\
\text { (21) }\end{array}$ & $\begin{array}{l}\text { Four falls } \\
(20)\end{array}$ & $\begin{array}{l}\text { Five falls } \\
\text { (8) }\end{array}$ & $p$ value \\
\hline \multirow{2}{*}{ Gender } & Male & $n(\%)$ & 205 & $84(39.4)$ & $74(36.8)$ & $26(41.3)$ & $10(47.6)$ & $8(40.0)$ & $3(37.5)$ & \multirow{2}{*}{$-0.942^{\mathrm{a})}$} \\
\hline & \multicolumn{2}{|c|}{ Female $n(\%)$} & 321 & $129(60.6)$ & $127(63.2)$ & $37(58.7)$ & $11(52.4)$ & $12(60.0)$ & $5(62.5)$ & \\
\hline Age (years) & \multicolumn{2}{|c|}{ Mean \pm S.D. } & $66.3 \pm 15.26$ & $66.6 \pm 15.39$ & $66.3 \pm 16.04$ & $66.8 \pm 13.78$ & $65.6 \pm 12.73$ & $66.0 \pm 15.36$ & $59.0 \pm 9.35$ & $0.840^{\mathrm{b})}$ \\
\hline \multicolumn{3}{|c|}{ Number of events } & - & 213 & 201 & 126 & 63 & 80 & 40 & \\
\hline
\end{tabular}

a) Chi-square test, b) Analysis of variance.

Table 2. Psychotropic Drug Use among Patients

\begin{tabular}{|c|c|c|c|c|c|}
\hline Category & Drug & Category & Drug & Category & Drug \\
\hline \multirow[t]{16}{*}{ Antipsychotics } & risperidone & Anxiolytics/ & triazolam & Antidepressants & fluvoxamine \\
\hline & perospirone & Hypnotics & zolpidem & & paroxetine \\
\hline & blonanserin & & zopiclone & & sertraline \\
\hline & olanzapine & & brotizolam & & milnacipran \\
\hline & quetiapine & & rilmazafone & & duloxetine \\
\hline & aripiprazole & & lormetazepam & & nortriptyline \\
\hline & perphenazine & & flunitrazepam & & amoxapine \\
\hline & chlorpromazine & & estazolam & & maprotiline \\
\hline & levomepromazine & & nitrazepam & & imipramine \\
\hline & haloperidol & & quazepam & & amitriptyline \\
\hline & timiperone & & etizolam & & clomipramine \\
\hline & bromperidol & & clotiazepam & & lofepramine \\
\hline & sulpiride & & lorazepam & & dosulepine \\
\hline & sultopride & & alprazolam & & trazodone \\
\hline & zotepine & & bromazepam & & mirtazapine \\
\hline & tiapride & & diazepam & & mianserin \\
\hline \multirow[t]{3}{*}{ Mood-stabilizers } & lithium carbonate & & cloxazolam & & setiptiline \\
\hline & sodium valproate & & chlordiazepoxide & & \\
\hline & carbamazepine & & ethyl loflazepate & & \\
\hline \multirow[t]{6}{*}{ Antiparkinsonisms } & biperiden & & clonazepam & & \\
\hline & trihexyphenidyl & & oxazolam & & \\
\hline & mazaticol & & amobarbital & & \\
\hline & amantadine & & bromovalerylurea & & \\
\hline & promethazine & & phenobarbital & & \\
\hline & hydroxyzine & & tandospirone & & \\
\hline
\end{tabular}

\section{2-2. 向精神薬の剂数と各向精神薬の併用状況} 各向精神薬の併用状況を確認する目的で, 向精神 薬の剂数と各向精神薬の併用剂数の関係を Fig. 1 に示した。縦軸には全向精神薬の併用剂数を，横軸 には各向精神薬の剂数の割合を示している. 気分安 定薬や抗パーキンソン薬は, 向精神薬の剂数が 3 剂 以上になると併用され始め, 向精神薬の剂数が 5 剂 以上になると $50 \%$ 以上併用されていた。 また，抗 うつ薬の場合も向精神薬の剂数が 3 剂以上になると 併用される割合が高くなる傾向がみられた。それに
対して抗精神病薬及び抗不安薬・睡眠薬は向精神薬 の剂数に関係なく最初から併用される傾向にあるこ とがわかった。

2-3. 転倒·転落の有無と向精神薬剂数の関係 転倒・転落の有無と向精神薬剂数の関係について ロジスティック回帰分析を行った結果，抗精神病薬 の剂数が 1 剂増えると転倒・転落リスクが 1.52 倍 になるという結果が得られた [Table 3(1)].

また, 気分安定薬, 抗精神病薬, 抗パーキンソン 薬，抗不安薬・睡眠薬，抗うつ薬それぞれの剂数を 

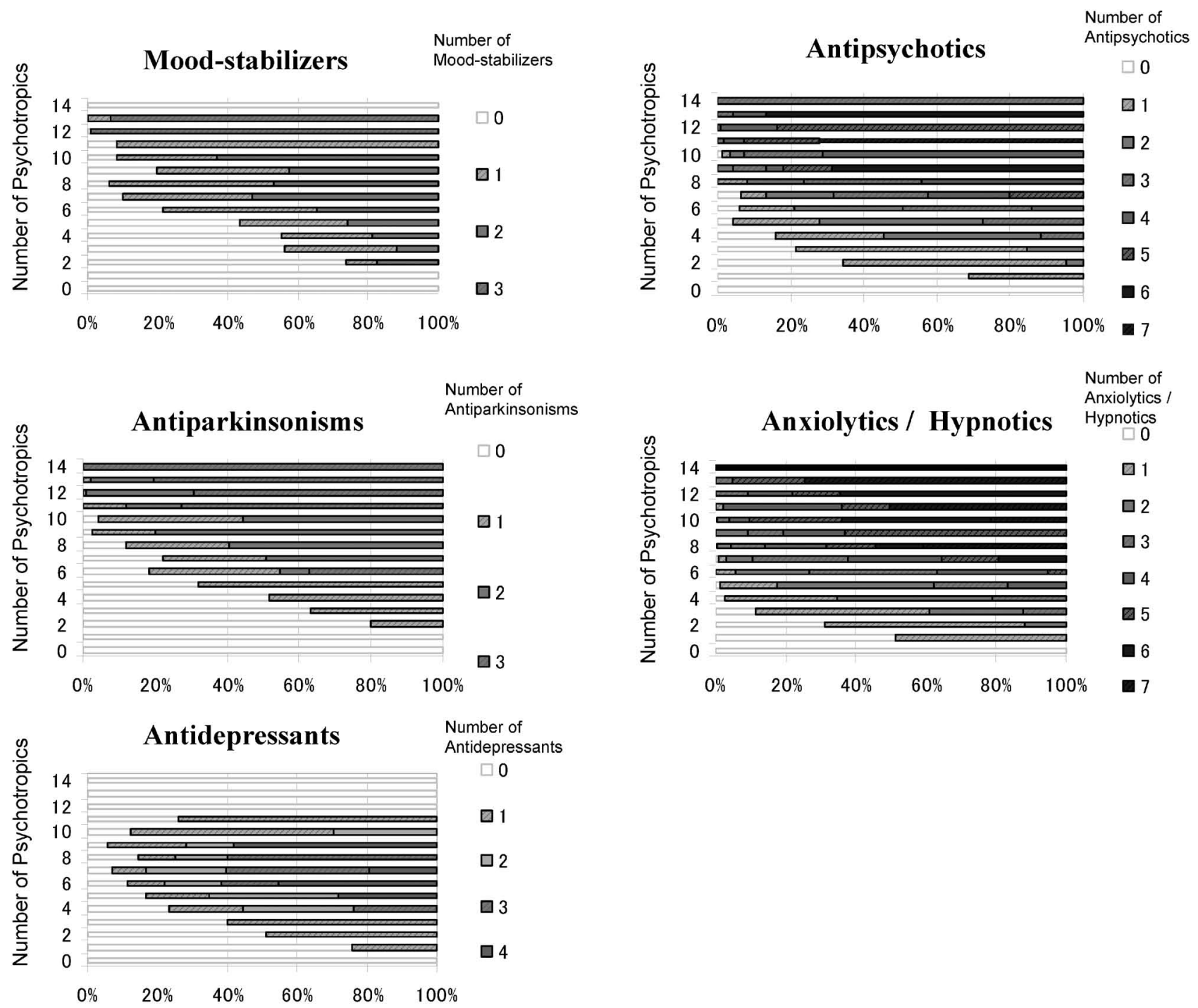

Fig. 1. Relationship between Number of Psychotropics and Number of Mood-stabilizers, Antiparkinsonisms, Antidepressants, Antipsychotics or Anxiolytics/Hypnotics

Table 3 Multiple Logistic Regression Analysis between Psycotropics and Risk of Fall

\begin{tabular}{clccc}
\hline \multicolumn{1}{c}{ Factor } & \multicolumn{1}{c}{ Variable } & Odds Ratio & $95 \%$ C.I. & $p$ value \\
\hline (1) All Psychotropics & Number of Psychotropics & 1.521 & $1.407-1.643$ & $<0.05$ \\
\hline \multirow{3}{*}{ (2) Category of Psychotropics } & Number of Antipsychotics & 2.627 & $2.104-3.279$ & $<0.05$ \\
& Number of Anxiolytics/Hypnotics & 1.290 & $1.112-1.495$ & $<0.05$ \\
& Number of Antidepressants & 1.243 & $0.950-1.626$ & 0.112 \\
\hline \multirow{2}{*}{ (3) Dose of Antipsychotics } & $\mathrm{CP} \geqq 600 \mathrm{mg}$ & 3.746 & $2.406-5.832$ & $<0.05$ \\
& $\mathrm{DAP} \geqq 15 \mathrm{mg}$ & 2.080 & $1.451-2.980$ & $<0.05$ \\
\hline
\end{tabular}

$\mathrm{CP}$ : dose of chlorpromazine equivalents, DAP: dose of diazepam equivalents.

説明変数としてステップワイズで多重ロジスティッ ク回帰分析したところ，抗精神病薬，抗不安薬・睡 眠薬の剂数は有意に転倒・転落リスクを増加させた
が，気分安定薬，抗うつ薬，抗パーキンソン薬は転 倒・転落リスクに影響しなかつた。抗精神病薬が 1 剂増えると転倒・転落リスクは 2.63 倍, 抗不安 
薬・睡眠薬が 1 剂増えると転倒・転落リスクは 1.29 倍となり，これらの結果から両剤が 1 剂ずつ 増えると転倒・転落リスクは $3.39(2.63 \times 1.29)$ 倍 となることがわかった [Table 3(2)].

2-4. 転倒 ·転落の有無と向精神薬の投与量の関 係転倒・転落リスクを有意に増加させた抗精神 病薬及び抗不安薬・睡眠薬の投与量との関係を解析 したところ，CP 換算量 $600 \mathrm{mg}$ 以上になると転 倒・転落リスクは 3.75 倍, DAP 換算量 $15 \mathrm{mg}$ 以上 になると 2.08 倍になり，これらの結果から CP 換 算量 $600 \mathrm{mg}$ 以上かつ DAP 換算量 $15 \mathrm{mg}$ 以上の場 合， $7.80(3.75 \times 2.08)$ 倍に増加するということが わかつた [Table 3(3)].

2-5. 向精神薬剂数と転倒 - 転落回数との関係

向精神薬剂数と転倒・転落回数との関係を Fig. 2 に示す. Figure 2 から，抗精神病薬については，転 倒・転落回数が 2 回以上では, 2 剂以上併用してい る割合が $50 \%$ を超えていることがわかった。ま
た，抗不安薬・睡眠薬については，転倒・転落回数 が 3 回以上になると 3 剂以上併用している割合が 40\%以上となることがわかった.

2-6. 投与量と転倒 ·転落回数及び剤数の関係

Figure 3 に抗精神病薬投与量 (CP 換算量) と転 倒・転落回数及び成数との関係を示した. Figure 3 から向精神薬の剂数が 5 剂以上になると CP 換算量 $600 \mathrm{mg}$ 以上の割合が増加し，CP 換算量 $600 \mathrm{mg}$ 以 上の割合の増加に伴い転倒・転落回数も増加する傾 向にあることがわかった。

Figure 4 にはベンゾジアゼピン系睡眠薬・抗不安 薬投与量（DAP 換算量）と転倒・転落回数及び剂 数との関係を示した.DAP 換算量においても先の $\mathrm{CP}$ 換算量と同様に，向精神薬の剂数が 5 剂以上に なると DAP $15 \mathrm{mg}$ 以上の割合が増加し，DAP 15 $\mathrm{mg}$ 以上の割合の増加に伴い転倒・転落回数も増加 する傾向にあることがわかった。

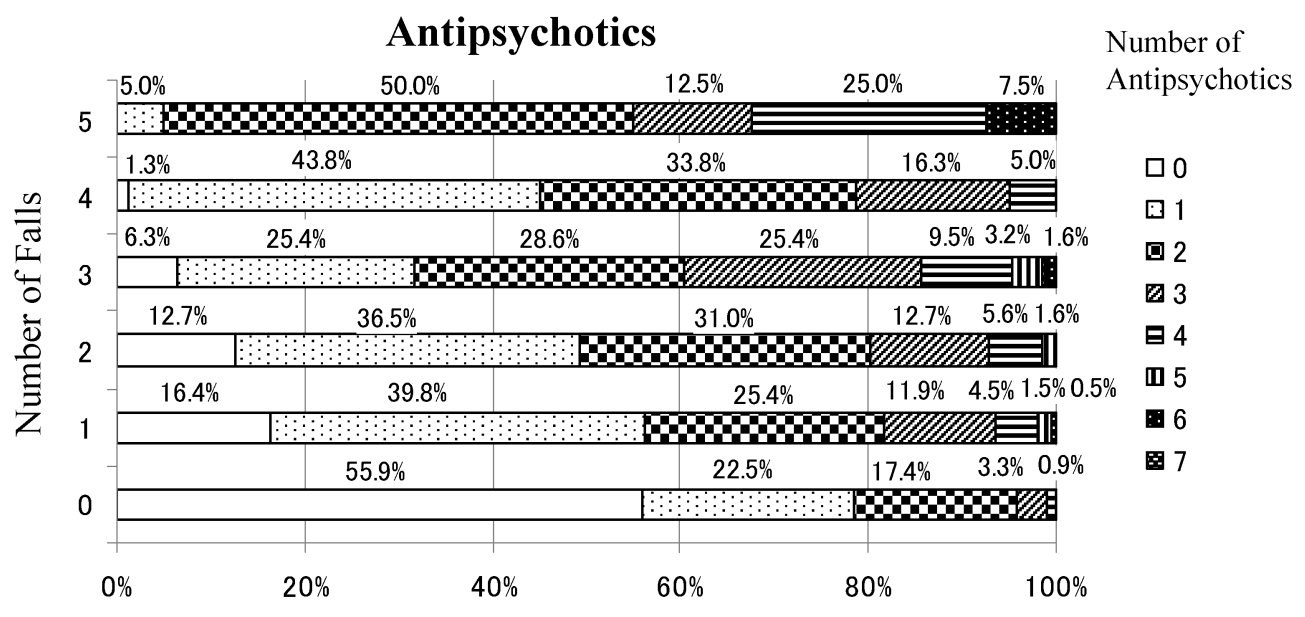

Anxiolytics / Hypnotics

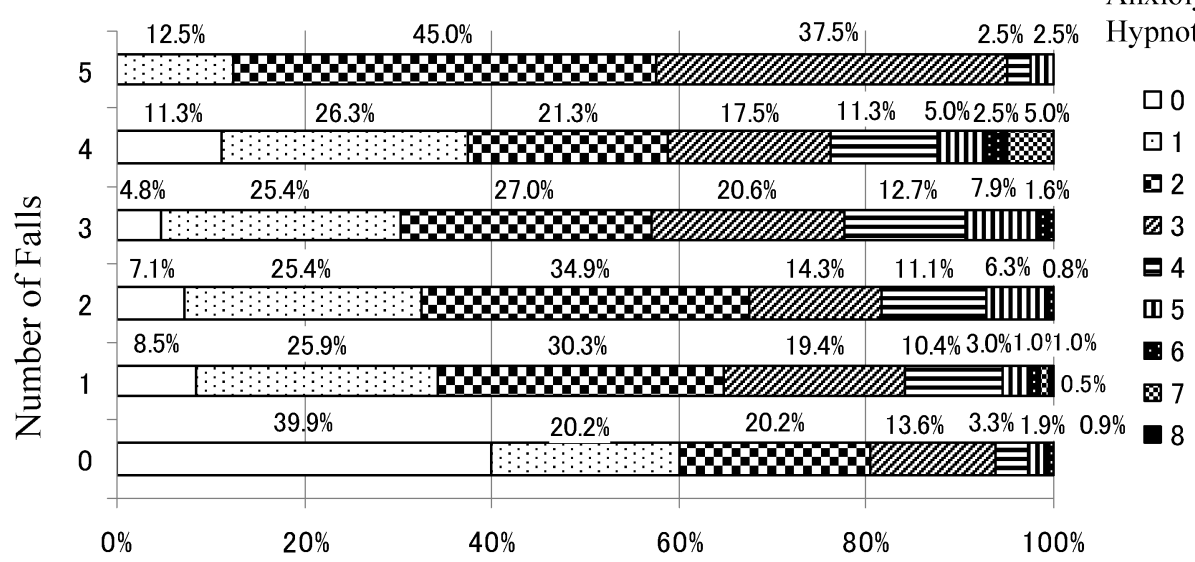

Fig. 2. Relationship between Number of Falls and Number of Antipsychotics or Anxiolytics/Hypnotics 

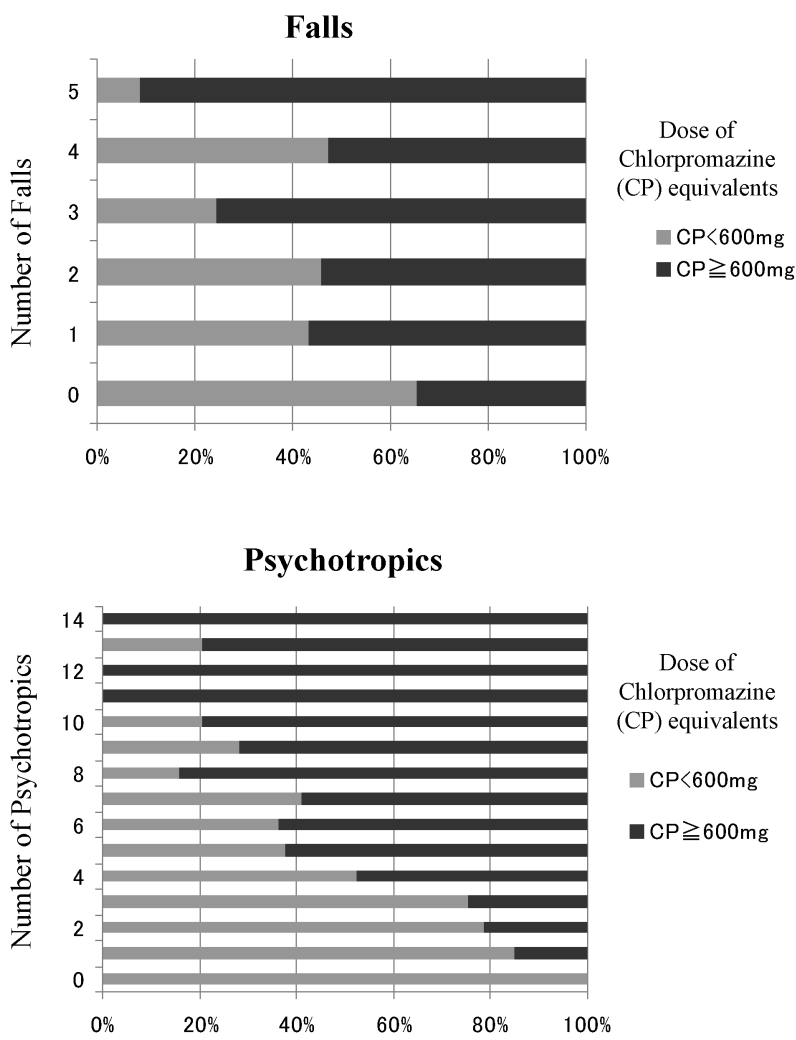

Fig. 3. Relationship between the Dose of Chlorpromazine (CP) -equivalents and Number of Falls or Psychotropics

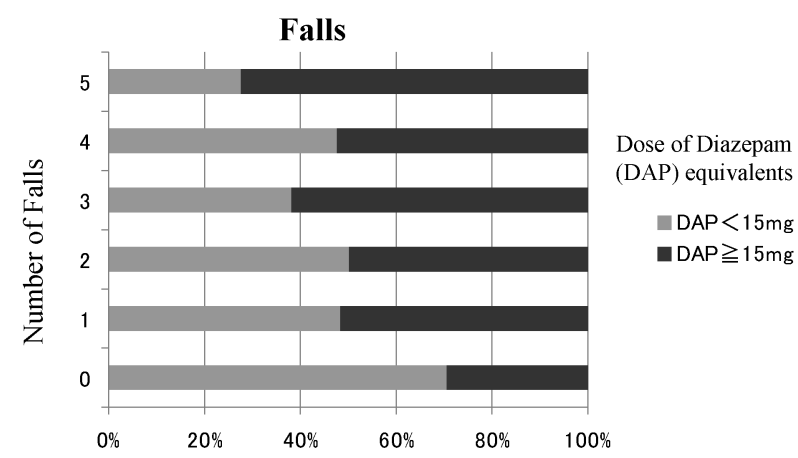

Psychotropics

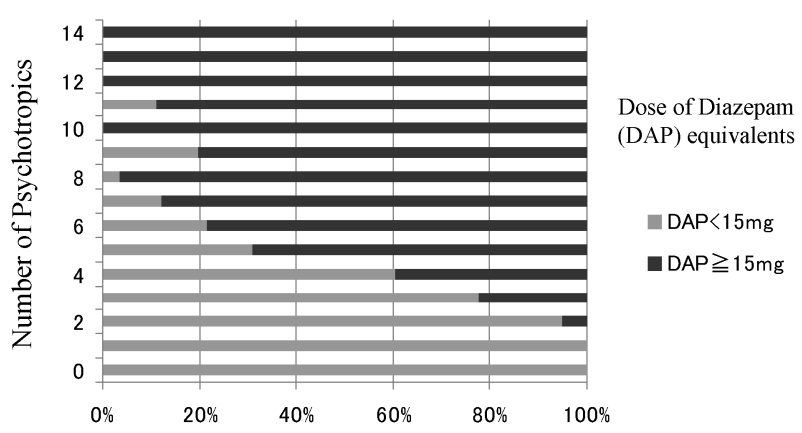

Fig. 4. Relationship between the Dose of Diazepam (DAP) equivalents and Number of Falls or Psychotoropics

\section{考察}

転倒・転落リスクは，これまで報告されていたべ ンゾジアゼピン系薬剂ばかりでなく，抗精神病薬に よっても増加するということが明らかとなった．向 精神薬の中止が転倒・転落リスクを低減できるとい う介入研究が報告されている. ${ }^{8)}$ しかしながら，抗 精神病薬は, 統合失調症及び気分障害の治療には欠 かすことのできない薬剤である，そのため，精神科 入院の患者の処方からこれらの薬剤をすべて中止す ることは難しい。近年，抗精神病薬の多剂併用大量 療法に関しては問題点が指摘され，単剂化・単純化 の試みがなされているのが現状である. ${ }^{9,10}$

精神科において向精神薬は併用されることが多 い. 抗精神病薬及び抗不安薬・睡眠薬は向精神薬の 剂数に関係なく最初から併用される傾向がみられ た。一方，気分安定薬や抗パーキンソン薬は，向精 神薬の剂数が 3 剂以上になると併用され始め, 向精 神薬の剂数が 5 剂以上になると $50 \%$ 以上併用され ていた．また，抗うつ薬の場合も向精神薬の剂数が 3 剂以上になると併用される割合が高くなる傾向が みられた（Fig. 1)。これは，抗精神病薬の増量に よって生じる副作用に対して使用されている薬剤が 向精神薬であることにもよると推察される.

われわれの研究結果では, 抗不安薬・睡眠薬が 1 剂増えることによる転倒・転落リスクの増加が 1.29 倍に対し，抗精神病薬が 1 剂増えることによ る転倒・転落リスクの増加は 2.63 倍であった [Table 3(2) ] ．このことは，精神科入院患者の転倒・ 転落リスクを考えるとき, 抗不安薬・睡眠薬ばかり でなく, 抗精神病薬の使用剂数に対しても注意を払 うべきであること示している.

$\mathrm{CP}$ 換算量 $600 \mathrm{mg}$ を基準にして抗精神病薬の投 与量と転倒・転落リスクを検討した結果, Table 3 (3) に示すように CP 換算量 $600 \mathrm{mg}$ 以上になると転 倒・転落リスクは 3.75 倍になるという結果を得 た。抗精神病薬は D2 受容体の $65 \%$ 占拠で臨床効 果が発現し，80\%以上の占拠で錐体外路症状が発現 すると言われており, ${ }^{11)} \mathrm{CP}$ 換算量では約 $600 \mathrm{mg} /$ day 前後であるとされている. ${ }^{12)}$ 抗精神病薬の剂数 と CP 換算量には正の相関があると言われてお り, ${ }^{9)}$ その剂数の増加は投与量の増加につながる. 今回の解析でも同様の結果が得られ，抗精神病薬の 
単剂化・単純化を推進することはその投与量を適切 な範囲に調整し，転倒・転落リスクをも低減させる ことにつながると考えられる.

抗不安薬・睡眠薬については DAP 換算量で比較 した結果，DAP 換算量が $15 \mathrm{mg}$ 以上になると転 倒・転落リスクは 2.08 倍となるという結果を得た [Table 3(3) ]．抗不安薬は，抗精神病薬や抗うつ薬 と併用されることが多く，また，精神疾患に伴う不 眠に対しては睡眠薬の併用も多く行われている。し かし，抗精神病薬の CP 換算量 $600 \mathrm{mg}$ 以上でかつ 抗不安薬・睡眠薬 DAP 換算量 $15 \mathrm{mg}$ 以上の場合, 転倒・転落リスクは 7.80 倍に増加し，それぞれの 投与量を併せて検討することの重要性が示唆された.

今回の調査では, 抗精神病薬については, 転倒 • 転落回数が 2 回以上では，2 剂以上併用している割 合が 50\%を超えており，また，抗不安薬・睡眠薬 については, 転倒・転落回数が 3 回以上になると 3 剂以上併用している割合が $40 \%$ 以上となった。こ のことから，抗精神病薬を 2 剂以上併用すると転 倒・転落回数が増える傾向，抗不安薬・睡眠薬を 3 剤以上併用すると転倒・転落回数が増える傾向があ ると考えられる（Fig. 2)。このことは，転倒・転 落が生じた場合に向精神薬，特に抗精神病薬及び抗 不安薬・睡眠薬の剂数を考慮して処方調整を行うこ とで，複数回の転倒・転落リスクを低減できる可能 性を示している.

また，向精神薬の剂数の増加に伴い， CP 換算量 $600 \mathrm{mg}$ 以上の割合及び DAP 換算量 $15 \mathrm{mg}$ 以上の 割合の増加がみられた。そして，転倒・転落の回数 も全体として，CP 換算量 $600 \mathrm{mg}$ 以上の割合及び DAP 換算量 $15 \mathrm{mg}$ 以上の割合の増加とともに多く なる傾向がみられた (Figs. 3 and 4)。このことは, これまでの研究11)で言われている通り剂数の増加が 投与量の増加につながり, さらには剂数の増加は, 転倒・転落リスクを増加させる原因となることを示 している.

以上をまとめると, 本研究では向精神薬剤数を 5 剤以内に調整し, 抗精神病薬の投与量を CP 換算量 $600 \mathrm{mg}$ 以内かつ抗不安薬・睡眠薬の投与量を DAP 換算量 $15 \mathrm{mg}$ 以内になるよう処方を調節すること によって，精神科の治療上必要な向精神薬を使用し ながら，転倒・転落リスクを低減できる可能性が示 唆された。また，個々の薬剤の影響因子について
は, 今回の研究では併用薬剂の剂数や投与量が複雑 であり解析することはできなかったが，検討すべき 重要な課題である.

今後は，精神科医療チームの中で薬剤師が向精神 薬を含む処方に対し転倒・転落リスクも考慮した上 で適切な薬物療法の処方設計に積極的に係わる必要 があると考える．また，剂数及び投与量の適正化を 図った上で，個々の薬剤の転倒・転落リスクに与え る影響について検討していく予定である.

\section{REFERENCES}

1) Hatakeyama T., Kumagai S., Journal of Health Science, Kyushu University, 26, 21-30 (2004).

2) Obara A., Phamaceuticals Monthly, 50, 97103 (2008).

3) Okuda T., J. Jpn. Soc. Hosp. Pharm., 48, 8588 (2012).

4) Waki Y., Yoshimi A., Senzaki K., Miyata H., Ito A., Soma T., Ueda Y., Mouri A., Yamada K., Ozaki N., Noda Y., Jpn. J. Pharm. Health Care Sci., 37, 475-480 (2011).

5) Shigeyama M., Taguchi M., Maeyama N., Yuhara H., Asado S., Nagata S., Kati T., Fujita K., Jpn. J. Pharm. Health Care Sci., 37, 49-55 (2011).

6) Ohtani M., Kikuchi T., Osawa K., Yamamura Y., Matsumoto S., Itou T., Sugiura M., Uchino K., Kimura S., Jpn. J. Pharm. Health Care Sci., 37, 253-260 (2011).

7) Inagaki A., Inada T., Jpn. J. Clin. Psychopharmacol., 9, 1443-1447 (2006).

8) Salonoja M., Salminen M., Vahlberg T., Aarnio P., Kivela S. L., Arch. Gerontol. Geriatr., 54, 160-167 (2012).

9) Yoshio T., Uno J., Nakagawa M., Hasegawa T., Sugimura K., Umeda K., Miwa K., Inagaki A., Inada T., Jpn. J. Clin. Psychopharmacol., 13, 1535-1545 (2010).

10) Yoshio T., Inada T., Uno J., Miwa T., Kitagawa K., Miyahara Y., Umeda K., Kato T., Inagaki A., Nabeshima T., Hum. Psychopharmacol. Clin. Exp., 27, 70-75 (2012).

11) Farde L., Wiesel F. A., Halldin C., Sedvall G., Arch. Gen. Psychiatry, 45, 71-76 (1988).

12) Lehman A. F., Steinwachs D. M., Schizophr. Bull., 24, 1-10 (1998). 